Persp. Teol. 32 (2000) 221-239

\title{
O DESAFIO DOS NOVOS MOVIMENTOS RELIGIOSOS ÀS IGREJ AS CRISTÃS
}

Manfredo Araújo de Oliveira

\section{A) O contexto sociohistórico de sua emergência}

Entre os analistas das sociedades contemporâneas há várias tentativas de captar o que especifica a vida societária atual. Neste horizonte há um fenômeno que desconcerta a muitos, e, contudo, é essencial para entender a sociedade hoje: o papel que os movimentos religiosos nela exercem. Muitos, no passado, consideraram o avanço da civilização técnico-científica como fator do desaparecimento inevitável das religiões: a ciência racional e sua técnica atribuíram-se competência em tudo, para a natureza e para o sujeito, para a configuração das formas de convivência social. O que se situava fora desta racionalidade não contava e não tinha importância na vida humana. A religião foi então situada na esfera do mito, do primitivo, do atrasado e infantil. Os mestres da suspeita foram mais longe, considerando-a alienação, incapacidade do indivíduo se assumir como sujeito da própria existência. Assim a racionalidade das novas ciências atribuía a si a responsabilidade exclusiva pela configuração da civilização humana, da sociedade e do mundo. O ser humano autônomo só tinha a ver com um mundo do saber, com uma natureza e com uma vida social por ele mesmos gestados e, por esta razão, eram sinais de sua autonomia. Mais recentemente, interpretações menos radicais afirmaram que a secularização da cultura não implicava necessariamente o desapare- 
cimento da religião, mas seu deslocamento, ou seja, a religião perderia sua significação pública e subsistiria na esfera da interioridade ${ }^{1}$.

Tudo indica que os cenários do mundo contemporâneo ${ }^{2}$ exigem um repensamento de nossas análises: da crise das religiões como tema dominante nos anos 70 e 80, - houve mesmo algum teólogo que chegou a elaborar uma teologia para os tempos pós-religiosos (H-G. Cox, por exemplo) - , passamos hoje a falar de "retorno do religioso", de "vingança de Deus" ${ }^{3}$ e até mesmo de "fim da secularização". Uma hipótese muito plausível, neste contexto, é que sem um diagnóstico e uma compreensão do fenômeno religioso e da situação das religiões não é possível analisar e compreender a situação espiritual da humanidade no fim deste milênio.

Também o Brasil contemporâneo é profundamente marcado pelo retorno do sagrado, que aqui, contudo, tem conotações específicas a partir do contexto sociohistórico que o caracteriza no presente. De alguma forma o Brasil é hoje, de modo desenvolvido, o que foi no passado. O primeiro problema que nos marcou como nação foi a dificuldade de dizer "nós", de nos constituirmos como um povo, com um perfil comum, já que o Brasil é fruto de sucessivas migrações de diferentes povos e etnias com diferentes costumes e tradições ${ }^{4}$. Daí a afirmação de J. H. Santos: "o homem brasileiro é a oposição sem identidade; chega a ser a indiferença dos extremos, que mal se relacionam entre si, malgrado séculos de convivência" ${ }^{5}$. Por esta razão, na festa do V Centenário do Descobrimento, retorna com força a pergunta: quem é o Brasil? Quem é o povo brasileiro?

Para H. Jaguaribe, a característica fundamental do Brasil está num dualismo básico, no fato de duas sociedades, radicalmente distintas,

\footnotetext{
${ }^{1}$ Cf. M.A. de OLIVEIRA, "A teoria da ação comunicativa e a teologia", Tempo Brasileiro, no 138 (1999) 117: "O agir comunicativo substitui, no curso da evolução social, o agir ritual (prática ritual) e é por esta razão que nos contextos modernos racionalizados de ação (prática de argumentação), os símbolos religiosos tornam-se incapazes de exprimir a identidade dos indivíduos e das coletividades, isto é, o consenso não é mais garantido pela religião, mas depende agora de uma formação racional da vontade". ${ }^{2}$ Cf. a respeito: J. DERRIDA / G. VATTIMO et alii, A Religião, Lisboa, 1997.

${ }^{3}$ Cf. L. KOLAKOWSKI, "A revanche do sagrado na cultura profana", Religião e Sociedade, $\mathrm{n}^{\circ} 1$ (1977) 153-162.

${ }^{4}$ Isto se manifestou na formação da religiosidade brasileira. Cf. F.C. ROLIM / J.B. FILHO / J. HORTAL, Novos movimentos religiosos na Igreja e na Sociedade, São Paulo, 1996, p 45: “Com os colonizadores europeus chegam o catolicismo ibérico (reconhecidamente singular) e a magia européia. Aqui se encontram com as religiões indígenas, cuja força irá impor-se, sobremaneira, por meio da mestiçagem. A escravidão trouxe consigo as religiões africanas, que, devido às adversidades, acabaram por engendrar um vasto sincretismo. No século XIX, dois novos elementos se acrescentam: o espiritismo europeu e alguns ingredientes do catolicismo romanizado".

${ }^{5}$ Cf. J.H. SANTOS, "Brava gente brasileira. Pequeno ensaio sobre sociedade e estado por ocasião do V Centenário" Veritas, vol. 44 / nº 4 (1999) 979.
} 
habitarem o mesmo espaço territorial e político: "De um lado, existe uma sociedade moderna, que opera em condições semelhantes às de um adiantado país europeu, uma economia industrial que já é a oitava do mundo ocidental. Essa sociedade, entretanto, inclui apenas uma parcela minoritária da população. Coexistindo com ela, no mesmo território e nas mesmas cidades, há uma sociedade primitiva que nos campos vive de uma pobre agricultura de subsistência, e nas cidades, de um miserável terciário, com cerca de $60 \%$ da população total" ${ }^{6}$. No decurso de nossa história, esta dualidade não encontrou meios eficazes para aproximar os extremos. Pelo contrário, o dualismo básico não alterou seus elementos constitutivos essenciais, mas foi encontrando expressões distintas, nas diversas situações de diferentes épocas. Assim se produziu tanto uma sociedade marcada pelo padrão da inserção externa, subordinada e dependente, como por uma organização social interna, radicada no monopólio da terra, na concentração brutal de riqueza, com profundas desigualdades sociais e regionais; ou seja, constituiu uma sociedade marcada por um cisão interna e profunda, aceita como não eliminável; tal situação gera nos pobres o sentimento de impotência. O eixo central desta problemática é a desigualdade na distribuição da riqueza, que tem como efeito uma enorme concentração de renda: hoje são 44 milhões de pessoas que sobrevivem em condições de extrema precariedade ${ }^{7}$, com uma renda mensal inferior a meio salário mínimo. Isto constitui a deformação de base da economia e da sociedade brasileiras, o que se mostra no fato de os $10 \%$ mais ricos possuírem $48 \%$ da renda nacional, com uma renda média familiar de US\$ 96.000 , enquanto $40 \%$ da população tem $8 \%$ da renda nacional com um renda familiar média de US\$ 1.000 por ano 8 . Tal condição se mostra visível na exploração do trabalho infantil, na multidão imensa dos sofredores de rua, nas condições miseráveis de vida dos trabalhadores, na violência física e cultural contra os povos indígenas, na discriminação de negros e mulheres.

Na situação atual, os "inempregáveis", gerados pela economia neoliberal mundializada, juntam-se à crescente população de marginais urbanos, aos camponeses empobrecidos e aos trabalhadores rurais sem terra, frutos de um sistema produtivo que defende a primazia absoluta do mercado, esvazia a participação política, dificultada inclusive pela fragmentação da sociedade civil. Tal sistema promove o individualismo, que normalmente desemboca num subjetivismo exacerbado de pessoas demasiadamente preocupadas consigo mesmas e

\footnotetext{
${ }^{6}$ Cf. H. JAGUARIBE, Alternativas do Brasil, Rio de Janeiro, 1989, 2a ed., pp. 9-10.

${ }^{7}$ A população brasileira, segundo as estimativas do IBGE, foi, em 1999, de 162.500 .000 habitantes. Já em 1996, 78, 4 \% da população era urbana.

${ }^{8}$ Cf. R. GONÇALVES, "Distribuição de riqueza e renda: alternativa para a crise brasileira", in I. LESBAUPIN (org.), O Desmonte da nação. Balanço do governo FHC, Petrópolis, 1999, pp. 45-74.
} 
indiferentes à sorte dos outros; desemboca num consumismo que estimula o psiquismo humano através da imaginação e da emoção. É um sistema que "procura forjar as pessoas de tal maneira que se deixem seduzir por uma procura insaciável do novo, do sonho, do desejo acima daquilo que já foi experimentado" ${ }^{\prime \prime}$. O Brasil ingressou de cheio no processo de superação das barreiras nacionais e na organização da produção a nível mundial, acoplada a um processo, também mundial, de "financeirização" da economia. Isto evidencia como os mercados financeiros, cada vez mais, impõem suas leis ao processo global de configuração da vida humana, o que nem melhora a repartição das riquezas nem cria empregos; entre nós, pelo contrário, tem criado uma massa imensa de pessoas que nada possuem e acorrem às grandes cidades, à busca de trabalho e educação. Este processo, portanto, não só não atenuou as desigualdades já antes existentes, mas as aprofundou: pobreza; desemprego e instabilidade são suas conseqüências estruturais. "Expatriados em seu próprio país, esses sem-nada perdem rapidamente o que ainda restava da cultura tradicional que os ligava à terra, centrada na produção de valores de uso, e se adaptam com dificuldade às relações de troca vigorantes na cidade. Aqui um novo ethos é requerido, no qual os valores tradicionais não mais vigoram. Os recémchegados ficam expostos, sem nenhuma defesa, aos costumes desse mundo estranho" ${ }^{10}$. Este processo como um todo gera um perigoso clima de desconfiança em relação às instituições democráticas ${ }^{11}$.

O grande canal introdutor a este mundo novo é a cultura eletrônica de massa, que gera um número crescente de espectadores e consumidores de imagens, enche-lhes a vida com a obsessão do consumo infinito, gera um processo objetivo de perda de sentido da identidade cultural com suas comunidades de origem ${ }^{12}$, abrindo-lhes o espaço a toda forma de mimetismo, a imitação da forma de vida dos ricos e dos países ricos, expressão nova de violência, uma vez que a sociedade moderna, com seus fascínios, permanecerá um sonho irrealizável para a maior parte deles ${ }^{13}$. A conseqüência imediata é o afrouxamento dos

${ }^{9}$ Cf. CNBB, Diretrizes gerais da ação evangelizadora da Igreja no Brasil, 1999-2002. = Documentos da CNBB, 61, p. 90.

${ }^{10}$ Cf. J.H. SANTOS, Op. cit., p. 984.

${ }^{11} \mathrm{O}$ empobrecimento das massas e o crescimento do crime organizado e do tráfico de drogas têm gerado um aumento assustador da violência e da criminalidade, cujas vítimas são, antes de tudo, os jovens do proletariado urbano, as crianças e as mulheres. ${ }^{12} \mathrm{O}$ que significa dizer que nossas sociedades são essencialmente pluralistas e o indivíduo se sente livre para compor seu universo de crenças. O pluralismo provoca a ruptura com um universo religioso monolítico e abre espaço para uma religiosidade difusa. Cf. L.R. BENEDETTI, "Entre a crença coletiva e a experiência individual: renascimento da religião", in M. F. dos ANJOS (org.), Sob o Fogo do Espírito, São Paulo, 1998, p. 63.

${ }^{13}$ Além das novas formas de dominação que se radicam nos próprios valores e ídolos da modernidade. Cf. J. COMBLIN, "O Cristianismo no limiar do terceiro milênio", in 
vínculos culturais de origem, provocado tanto por meio das migrações intensas como através da invasão cotidiana de imagens; estas alimentam o universo simbólico através do meios de comunicação. Chega-se, assim, ao que se poderia chamar "crença no relativo": tudo é transformado em provisório e passageiro, uma vez que o desenraizamento ataca as imagens estáveis do mundo, a memória coletiva e a cosmovisão que permitem aos indivíduos o sentirem-se em casa, em seu proprio mundo ${ }^{14}$. "A afetividade, que só se realiza na relação pessoal de mútuo respeito e acolhida, é permanentemente recalcada na moderna sociedade pobre. Pesa sobre os pobres o fardo do silêncio, da contenção dos próprios sentimentos e desejos" ${ }^{15}$.

Os meios de comunicação fazem chegar aos pobres as ilimitada propostas de novos sentidos para a vida, cada uma tentando imporse como sentido englobante; isto caracteriza o clima espiritual de fim de século, revela a efetivação da ruptura daquela unidade simbólica que assinalava as sociedades tradicionais. Defende-se hoje a idéia de que, ao invés de uma única razão de vida, teríamos uma multiplicidade infinita de razões, de múltiplos subsistemas e jogos de linguagem, porém sem qualquer unidade entre elas. A razão una e universal, capaz de articular um sentido unitário para nossas vidas, integrando as diferentes esferas do real, é considerada algo do passado, pois o que interessa agora não é mais o uno, o imutável e o eterno, mas a diferença, o contingente e o histórico, e com ele, o fragmentário e episódico. Tornou-se impossível unificar o múltiplo. O que se impõe é a dispersão, a descentralização, a indeterminação e a pluralidade. A ênfase está agora no singular, não no universal. Difunde-se o relativismo quanto a todas as posições, a impossibilidade de decidir racionalmente as questões fundamentais da existência, uma oposição radical à absolutização da razão na vida humana. Por isto emerge, como a atitude mais conveniente à vida humana, um ceticismo pragmático que nos deixa, afinal, em paz em relação à verdade da vida teórica e prática, na medida em que se renuncia a toda possível utopia de unidade na existência humana, a toda reconciliação ou harmonia universal. Com isto perdem credibilidade as importantes crenças que no passado canalizaram as energias da humanidade. As grandes causas, sobretudo as promessas modernas de liberdade, igualdade, progresso e desenvolvimento, parecem para sempre perdidas. Neste contexto as aten-

C. CALIMAN (org.), A Sedução do Sagrado. O fenômeno religioso na virada do milênio, Petrópolis, 1999, 2a . ed., p. 147: “Em nome desses valores, o que se cria é um sistema de dominação, privilégios, exploração do ser humano pelo ser humano".

${ }^{14}$ Cf. E. PACE, "Religião e Globalização", in A.P. ORO / C.A. STEIL (orgs.), Globalização e Religião, Petrópolis, 1997, pp. 25-42.

${ }^{15}$ Cf. J.B. LIBANIO, Fascínio do Sagrado, [mímeo], Belo Horizonte, 1999, p.5. 
ções se voltam para as pequenas causas, para o fragmentário e instantâneo. Tal sociedade gera, por um lado, grande insegurança, muita incerteza; por outro, leva a uma busca de respostas utilitárias e imediatas aos problemas humanos ${ }^{16}$.

Certamente a partir deste clima espiritual a sociedade brasileira caminha para uma abertura e tolerância, inclusive religiosa, em relação ao diferente, o que constitui sem dúvida uma conquista humanizante. Porém abre-se o espaço para uma espécie de subjetivação da fé que leva, muitas vezes, a pessoa a construir seu mundo religioso a partir de elementos de diferentes procedências, de acordo com preferências puramente subjetivas, sem pertença a qualquer instituição eclesial, ou passagem permanente de uma instituição a outra, ou, ainda, apenas adesão parcial a uma delas. Com isto a religião tende a se transformar numa conviç̧ão interior, invisível ${ }^{17}$, com forte insistência na dimensão emocional e na dimensão terapêutica, pela busca de curas e de soluções para problemas individuais, familiares e profissionais ${ }^{18}$. Mas há, também, a perda dos referenciais últimos, sem os quais é impossível tomar posição séria em relação às questões fundamentais da vida humana: a questão do mal, do sentido radical da vida, da salvação. Os seres humanos se alimentam também de significados, desejos e sentidos ${ }^{19}$. Isto se torna mais premente num mundo que renunciou a qualquer sentido englobante, onde a dúvida deixou de ser um esforço filosófico e se transformou num destino da civilização ${ }^{20}$.

Neste contexto, o poder do Estado foi submetido aos interesses privados, de modo que o espaço público foi privatizado. O desafio central de uma sociedade com estas características só pode ser a configuração de um modelo novo de convivência social capaz de combater a pobreza e promover a inclusão das massas miseráveis e abandonadas, o que implica a efetivação de direitos sociais elementares.

\footnotetext{
${ }^{16}$ É por esta razão que há autores que se perguntam ou negam que se trate propriamente de religião. Cf. A. ANTONIAZZI, "O Sagrado e as Religiões no limiar do terceiro milênio", in C. CALIMAN (org.), Op. cit. p. 13: "Não é a busca de Deus ou da verdade que anima estas experiências religiosas; é a satisfação das necessidades pessoais".

${ }^{17}$ Cf. Th. LUCKMANN, La religione invisibile, Bologna, 1967.

${ }^{18}$ Cf. A. ANTONIAZZI, Op. cit., p. 16: “A religião atual .... não é tanto servir a Deus, quanto, em certo sentido, servir-se de Deus. Ela se transforma num lugar de solução de problemas, de cura dos nossos males, de consolo ou compensação".

${ }^{19}$ Cf. G. BATAILLE, Teoria da religião, São Paulo, 1973, p. 21.

${ }^{20}$ Cf. M. FRAIJÓ, Fragmentos de esperança: notas para uma filosofia da religião, São Paulo, 1999, p. 52.
} 


\section{B) Análise fenomenológica dos novos movimentos religiosos}

É inegável que o surto religioso em nossos dias é um fenômeno complexo e constitui, por isto, um estímulo forte para as interpretações sociológicas. Uma das mais provocadoras é a da socióloga francesa Hervieu-Léger ${ }^{21}$, para quem, sem dúvida, como em muitas outras interpretações, o ponto fundamental de referência deve ser a modernidade. A questão central é saber como, de algum modo, a modernidade nos pode ajudar a entender a explosão religiosa de nossos dias. Hervieu-Léger, seguindo M. Weber, entende a modernidade como processo de racionalização que ela interpreta em sua dimensão histórica e em sua dimensão utópica, ou seja, enquanto horizonte e projeção imaginária desse processo. Sua hipótese fundamental de interpretação é que a modernidade, enquanto processo histórico, dissolve a religião, mas a reconstitui enquanto utopia, pois repõe permanentemente as condições de um pensamento que considera a distância entre a realidade vivida e o horizonte utópico com a expressão e resultado da tensão entre dois mundos antagônicos: o mundo cotidiano e o mundo das significações ${ }^{22}$.

O paradoxo da modernidade ${ }^{23}$ precisamente consiste no fato de que, na medida mesma em que a racionalidade moderna interpreta a modernidade como um processo aberto, como uma tarefa a realizar no mundo, só pode funcionar no interior desta tensão que lhe é constitutiva. Deste modo, se a modernidade abole a religião como sistema de significações capazes de mover a vida humana, cria o espaço a uma utopia, situada numa esfera afim à religião, sendo que aí se tematizam as questões da finalidade e da salvação da vida humana. Neste contexto, as representações religiosas emergem como conjunto de construções ideais, que resolvem simbolicamente a contradição entre a vida concreta e a esfera dos valores e fins, de modo que seu lugar próprio na vida humana é a esfera do utópico, constantemente recriada na vida humana. As religiões são assim reservatórios inesgotáveis de significações utópicas. Os novos movimentos religiosos se alimentam das contradições da modernidade porque ela é essencialmente contraditória. Nesta perspectiva, a secularização não pode significar o desaparecimento da religião, mas o trabalho de sua rearticulação numa

\footnotetext{
${ }^{21}$ Cf. D. HERVIEU-LÉGER, Vers un nouveau christianisme?: Introduction à la sociologie du christianisme occidental, Paris, 1987; Le pélerin et le converti, Paris, 1999.

${ }^{22}$ Cf. J. MIRANDA, Horizontes de Bruma. Os limites questionados do religioso e do político, São Paulo, 1995, pp. 92ss.

${ }^{23}$ É por isto que, para ela, a modernidade, que se anunciava, na década de 70, como a-religiosa, porque governada pela razão científica, é uma nebulosa de crenças. Cf. D. HERVIEU-LÉGER, Le pélerin ..., Op. cit., p. 12.
} 
sociedade estruturalmente impotente para satisfazer as expectativas que ela é obrigada a suscitar para continuar existindo" ${ }^{24}$.

De qualquer forma, no Brasil, a referência à modernidade e no modo específico em que se realizou entre nós, é a referência obrigatória para compreendermos as duas vertentes principais dos novos movimentos religiosos ${ }^{25}$ que marcam a cena pública do Brasil contemporâneo: o neopentecostalismo evangélico ${ }^{26}$ e a renovação carismática católica.

As análises sociológicas sobre o pentecostalismo ${ }^{27}$ brasileiro insistiram em sua função de ajustamento e integração social. Num Brasil recentemente urbanizado, com grandes cidades repletas de migrantes, esta religião, composta de milhares de comunidades fraternas, tornouse a grande mediação para o ajustamento e integração social dos indivíduos das classes pobres e marginalizadas, de origem rural. Tal religião recriava, no mundo urbano, as formas de contato primário, baseadas nos preceitos bíblicos, que constituíam o mundo destas populações, vivido antes no campo. "Com o propósito de superar as precárias condições de existência, organizar a vida, encontrar sentido, alento e esperança perante situação tão desesperadora, os estratos mais pobres, mais sofridos, mais escuros e menos escolarizados da população, isto é, os mais marginalizados - distantes do catolicismo oficial, alheios a sindicatos, desconfiados de partidos e abandonados à própria sorte pelos poderes públicos —, têm optado preferencialmente

\footnotetext{
${ }^{24}$ Ela interpreta a religiosidade contemporânea como a passagem da religião perdida para o "religioso por todas as partes", uma vez que a religião volta com força à cena política no cerne das sociedades ocidentais. Cf. D. HERVIEU-LÉGER, Le pélerin ..., Op. cit., pp. 16 ss.

${ }^{25}$ Cf. J. B. FILHO, et alii, Novos movimentos religiosos na igreja e na sociedade, São Paulo, 1996.

${ }^{26}$ Cf. A. CORTEN, Os pobres e o Espírito Santo: o pentecostalismo no Brasil, Petrópolis, 1996. O Brasil, em números absolutos, é o maior país evangélico da América Latina. Cf. R. MARIANO, Neopentecostais: Sociologia do novo Pentecostalismo no Brasil, São Paulo, 1999, p. 10: "O Censo Demográfico do Instituto Brasileiro de Geografia e Estatística (IBGE) de 1991 revelou a existência de 13.189 .282 evangélicos $(8,98 \%)$ na população brasileira. Embora a cifra esteja abaixo das expectativas mostra que, na década de oitenta, os evangélicos cresceram $67,3 \%$, 2,8 vezes mais do que a população brasileira, a maior diferença do século entre as taxas de crescimento evangélico e populacional. Projetando a taxa de crescimento anual $(5,18 \%)$ destes religiosos na década de oitenta para 1998, encontramos cerca de 20 milhões de evangélicos no país". No Censo de 1991, os pentecostais representavam $65,1 \%$ dos protestantes do país. O crescimento se concentra nos estratos mais pobres da população $(61 \%$ dos pentecostais recebiam até dois salários mínimos. Entre eles está o maior número de analfabetos, de desempregados, de pardos e negros).

27 A respeito do lugar do pentecostalismo dentro do contexto do protestantismo brasileiro cf. J. B. FILHO, "Os Caçadores da identidade perdida: o protestantismo histórico brasileiro às voltas com os pentecostalismos", in M. F. dos ANJOS (org.), Sob o Fogo ..., Op. cit., pp. 211-227.
} 
pelas igrejas pentecostais. Nelas, encontram receptividade, apoio terapêutico-espiritual, e, em alguns casos, solidariedade material" ${ }^{28}$. Mas aqui se revela uma situação paradoxal, uma vez que, no interior da modernidade, a integração era feita pela forte desvalorização do mundo moderno; "em vez de levar o crente a estabelecer compromissos com este mundo, implicava contrapartida fortemente contracultural, sectária e ascética, fundamentada na crença do iminente Segundo Advento de Cristo e na radical dicotomia entre os reinos material e espiritual" ${ }^{29}$. A grande tarefa do fiel, no horizonte desta visão dualista da vida, era desligar-se das coisas, interesses e paixões mundanos, morrer para este mundo, fechar-se em casa e na igreja e resguardarse puro e santo para a volta de Cristo no juízo final.

Enquanto a grande maioria dos fiéis era pobre, o sectarismo e o ascetismo pentecostais, de inspiração puritana, não geraram grandes tensões internas. Isto foi mudado radicalmente nas duas últimas décadas, no meio do que se chama "neopentecostalismo"; aqui a questão central é libertar do diabo as pessoas e conseguir prosperidade financeira, saúde e triunfo nos empreendimentos em meio à sociedade moderna, que, cada vez mais, atrai os fiéis com promessas de consumo, de serviços de crédito ao consumidor, de apelos da moda e opções de lazer produzidas pela indústria cultural. Estas igrejas vão realizar profundas acomodações à sociedade, abolindo muito do que era distintivo de sua tradição e criando novos ritos, crenças e práticas, que priorizam a vida aqui e agora, de modo que possam ir "ao encontro dos modos de reestruturação da personalidade e da escala de valores que as pessoas são compelidas a efetuar no contexto urbano-industri$\mathrm{al}^{\prime \prime}{ }^{30}$. Estar unido a Deus vai significar, então, gozar uma vida próspera e feliz neste mundo, que é o lugar da felicidade, de tal modo que a nova teologia leva o fiel a estabelecer sólidos compromissos com o mundo moderno, seus valores e seus prazeres ${ }^{31}$. A grande meta pastoral se torna um ajustamento gradativo da mensagem e das exigências religiosas às novas condições de vida, de tal maneira que se produza uma nova cultura religiosa de massa.

A teologia assume então a forma de uma "teologia da prosperidade". Essa doutrina surgiu na década de 40 , reunindo crenças sobre cura, prosperidade e poder da fé. Mas só se constituiu como movimento doutrinário no decorrer dos anos 70 , quando encontrou guarida nos grupos evangélicos dos EUA, pelos quais adquiriu visibilidade e

\footnotetext{
${ }^{28}$ Cf. Mariano R., Neopentecostais, Op. cit., p. 12.

${ }^{29}$ Cf. R. MARIANO, "Neopentecostalismo: nova maneira de ser pentecostal", in M.F. dos ANJOS (org.) Sob o Fogo ..., Op. cit., p. 20.

${ }^{30}$ Cf. J.B. FILHO, Op. cit., p. 225.

${ }^{31}$ Cf. R. MARIANO, Neopentecostais. Sociologia do novo pentecostalismo no Brasil, São Paulo, 1999, p. 147ss.
} 
se difundiu para outras correntes cristãs" ${ }^{32}$. Os neopentecostais querem enriquecer, gozar, armazenar tesouros na terra; portanto nada têm do ascetismo puritano. A fé inabalável constitui o elemento fundamental para conseguir estas bênçãos. Os cristãos, em nome de Jesus, devem reivindicar, e mesmo exigir a posse desses bens a que têm direito, já que participam da natureza divina e, portanto, do poder de Deus de, pela palavra, chamar coisas à existência. "O plano de Deus para o homem é fazê-lo feliz, abençoado, saudável e próspero em tudo" ${ }^{33}$ e só não consegue tudo isto quem não tem fé, não cumpre o que diz a Bíblia e se envolve direta ou indiretamente com o diabo. A fé em Deus emerge assim como meio eficaz para obter saúde, riqueza, felicidade, resolução de problemas afetivos. Portanto pobreza é falta de fé, pois Jesus veio pregar o evangelho aos pobres para que eles deixassem de ser pobres, uma vez que o Cordeiro de Deus libertou os seres humanos do diabo e das maldições da miséria, da enfermidade nesta vida e da morte eterna no além.

Isto implica uma mudança radical em relação ao mundo moderno: não se trata mais de combater o mundo pela fuga, mas antes através de seu enfrentamento, da conquista ${ }^{34}$ de suas diferentes áreas, através da ousadia missionária a fim de tomar posse para Deus, pela guerra espiritual, das coisas de que o diabo se apoderou. Imbuído de espírito guerreiro e triunfalista, o neopentecostal se propõe a enfrentar corajosamente o próprio diabo. Daí o proselitismo agressivo: adotam-se os mais diferentes meios de evangelização. Prega-se no carnaval, nas zonas de prostituição, no rádio e na TV, em eventos esportivos, nas romarias da igreja católica, etc.; usa-se trios elétricos, filmes em vídeo, técnicas publicitárias, bonés, adesivos, camisetas, ritmos e estilos musicais da moda, shows evangélicos em igrejas e estádios. Teatros, cinemas, fábricas e supermercados são transformados em templos.

A novidade neste contexto é o número crescente de convertidos da classe média: empresários, uma variedade de profissionais, artistas, atletas, modelos, cantores, políticos, fato que tem possibilitado novas chances de participação social para os crentes destas igrejas, como também na militância sindical e partidária, numa perspectiva normalmente corporativista ${ }^{35}$ e conservadora, com forte inclinação a posições de direita. Trata-se de grupos antiintelectuais e antiecumênicos, cujo

\footnotetext{
${ }^{32}$ Cf. ibidem, p.151.

${ }^{33}$ Cf. R. R. SOARES, As bênçãos que enriquecem, Rio de Janeiro, 1985, p. 141.

${ }^{34}$ Cf. G. KEPEL, A revanche de Deus: cristãos, judeus e muçulmanos na reconquista do mundo, São Paulo, 1991.

${ }^{35}$ Cf. R. MARIANO, Op. cit., p. 34: "Seu corporativismo, porém, costuma ser prontamente mobilizado quando se trata de defender questões de interesse imediato das igrejas que os elegeram, como a defesa, sempre intransigente, de privilégios fiscais e a oposição ferrenha a projetos de lei que estabeleçam ou impliquem penalidades à poluição sonora dos cultos".
} 
objetivo básico é, mediante a conversão individual, a pregação da moral cristã e o uso da mídia e do exercício de mandatos políticos, restabelecer a dominação cristã no Estado e na vida privada. Isto mostra que, em contraposição ao passado, estes grupos pretendem ter voz e vez no mundo moderno. Trata-se de uma religião que está interessada em orientar sua mensagem para este mundo, não para transformá-lo revolucionariamente, mas com o intuito de se ajustar às demandas sociais das massas, interessadas imediatamente na solução de seus problemas cotidianos e na satisfação de seus desejos. Por esta razão, oferece aos fiéis bens de fácil acesso, como a oração para sanar infortúnios familiares, afetivos, financeiros.

Há uma mudança profunda de mentalidade: ao invés do espírito fortemente comunitário do passado, os fiéis se tornam cada vez mais individualistas, consumistas e hedonistas, cada vez mais portadores da mesma mentalidade que marca a sociedade contemporânea. A conversão neopentecostal deixou de implicar uma mudança cultural profunda em relação ao ambiente cultural vigente. Ela renuncia a controlar o tipo de corte de cabelo de seus fiéis, a padronizar seu vestuário e aparência, desiste de impor limites ao lazer e na busca do prazer. Numa palavra, para sobreviver num país altamente secularizado como é o Brasil de hoje, as igrejas pentecostais optaram por abrir mão de preceitos, valores, tradições, tabus e interpretações do cristianismo que deixaram de ser funcionais e anacrônicos para a sociedade atual. Sem dúvida uma das razões do sucesso dessa nova postura é sua capacidade de ajustamento à mentalidade vigente.

O extraordinário é que este processo de adaptação ao mundo deixa intocado certo universo teológico na medida em que o pensamento mágico e mítico continua presente e é reavivado no culto; constitui-se mesmo uma das forças motrizes do neopentecostalismo ${ }^{36}$, que tende a se apresentar como uma religião sem grandes exigências, a não ser quanto ao lado financeiro: o pecado de Adão e Eva rompeu a comunhão entre Deus e o ser humano e o fez escravo do diabo; os demônios atuam sob a direção de Satanás para levarem os seres humanos à miséria e à pobreza. Atribui-se ao diabo a fonte de inteligibilidade dos problemas sociais e individuais, pois o que se passa na história é entendido como decorrência de uma guerra entre duas forças, a divina e a demoníaca, num mundo espiritual de que os seres humanos, de alguma forma, participam. "O demônio entra no jogo religioso de diversas maneiras. Serve para desqualificar as outras formas religio-

\footnotetext{
${ }^{36}$ Pode-se perguntar se as confissões cristãs na modernidade, de alguma forma, não atrofiaram a dimensão experiencial da fé e se concentraram nas disputas interconfessionais, numa linha moralizante e na execução material de ritos. Cf. W. ALTMANN, "Experiência e teologia na tradição protestante", in M. F. DOS ANJOS (org.), Sob o Fogo ..., Op. cit., pp. 165-173. J.B. LIBANIO, Fascinio ..., Op. cit., p.5.
} 
sas, especialmente as afro-brasileiras, cujas divindades, orixás personificam para os pentecostais o próprio demônio" ${ }^{37}$. Trata-se de enfrentar, com força e empenho, o inimigo da humanidade nesta guerra cósmica entre Deus e o diabo.

Neste processo a explicação dos problemas históricos é aqui não histórica, ao contrário do que se dá através da teologia da libertação: o universo está divido em dois reinos: o reino espiritual e o reino material; a guerra espiritual é necessária, porque a presença e a ação do diabo estão em todos os lugares e em todas as coisas: os demônios são responsáveis por todos os males que afligem a humanidade.

Os demônios estão presentes, sobretudo, nas religiões mediúnicas, as maiores concorrentes das igrejas neopentecostais no mercado de soluções simbólicas para os problemas que afligem as grandes massas. Os pastores acreditam que as divindades e entidades afro-brasileiras e espíritas são demônios, com a capacidade de realizar milagres e curas, mas que, em última instância, produzem o mal e se apropriam das pessoas. Os pastores humilham o diabo e o expulsam das pessoas, através dos rituais de libertação, para a demonstração do poder de Cristo. De tal maneira que a possessão demoníaca se tornou elemento constitutivo da imagem destas igrejas.

Neste horizonte, a responsabilidade pessoal pelo que ocorre é praticamente nula, uma vez que as pessoas são consideradas, antes de mais nada, vítimas da tirania do diabo. Ele se transforma numa figura central na religião, cuja tarefa específica é a de combater e vencer tal inimigo forte e poderoso, e atestar, desta forma, seu próprio poderio espiritual.

Para se libertarem do diabo, os fiéis devem dar ofertas ${ }^{38}$ com desprendimento; são aconselhados a deixar de ser meros empregados e a participar da corrente da prosperidade, abrindo negócios, aproveitando todas as oportunidades para se enriquecerem e a se tornarem patrões. Deus lhes faz uma proposta muito simples: a Ele os homens entregam, pela mediação da igreja, dez por cento do que têm e recebem em troca bênçãos sem medidas, isto é, o cumprimento das promessas divinas, na recompensa material aos pagadores do dízimo. Portanto o relacionamento entre Deus e o ser humano é contratual. Por isto grande parte do culto destas igrejas tem como objetivo básico convencer os fiéis da obrigação do pagamento do

\footnotetext{
${ }^{37}$ Cf. J.B. LIBANIO, Plausibilidade do Cristianismo histórico nos dias atuais, Belo Horizonte (mimeo), 1999, p. 13.

${ }^{38}$ Cf. W. GOMES, "Nem anjos, nem demônios", in A. ANTONIAZZI et alii, Nem Anjos, nem Demônios. Interpretações sociológicas do pentecostalismo, Petrópolis, 1994, pp. 225-270.
} 
dízimo. O desempenho dos pastores é avaliado a partir de sua habilidade em conseguir ofertas.

O sucesso está radicado basicamente no milagre, na magia, na experiência extática, no transe, na manipulação das emoções, ou seja, numa série de práticas proibidas, tanto pelo protestantismo tradicional, como pela igreja católica. Respondem, de alguma forma, à busca atual de transcendência, de harmonia interior, de paz e de consolo, mesmo que se diga que este "tipo de participação não responde aos anseios específicos da modernidade nas suas expressões democráticas. Nessas igrejas, não há nada de democracia em sua gestão, especialmente no campo econômico" ${ }^{39}$.

O efeito fundamental destas práticas é a catarse das massas, a reatualização de pensamentos e visões de mundo arcaicos, a restauração das forças psíquicas e espirituais. Tudo isto toma formas empresariais modernas, é exibido diariamente na mídia eletrônica e aceito pelas massas ainda marcadas por práticas e sensibilidades medievais, muito distanciadas do discurso e das práticas oficiais do catolicismo romano. Em linguagem direta e simples, sobre todos os problemas da vida cotidiana, em ritmo de torcidas organizadas e de programas televisivos de auditório, o discurso destas igrejas procura dar sentido à vida e ajudar as pessoas a superar estas aflições. "As músicas, os aplausos, as intervenções do dirigente com chamadas insistentes, a repetição mântrica de alguns versículos bíblicos, os gritos, cenas histéricas formam um conjunto que leva as pessoas a um clímax de comoção" ${ }^{40}$.

O cenário atual da vivência religiosa dos católicos é bastante diferenciado.

V. Feller ${ }^{41}$ distingue seis tipos de vivência da fé católica no atual contexto brasileiro: a) $\mathrm{O}$ tradicionalismo das elites, que têm uma visão fixista da fé desligada da vida; b) O tradicionalismo do povo: a religiosidade popular, vivência profunda, mas em termos pré-modernos com uma visão fatalista e determinista da religião, passiva diante das injustiças; c) Catolicismo paroquial, tradicional ou renovado na linha do Vat. II; d) O catolicismo social com empenho de inspiração cristã na transformação da sociedade através das CEBs, pastorais sociais e movimentos populares; e) Catolicismo privativo: acento na dimensão emocional da fé e participação em movimentos de expressão espiritu-

\footnotetext{
${ }^{39}$ Cf. J.B. LIBANIO, Op. cit., p. 16.

${ }^{40}$ Cf. ibidem, pp. 13-14.

${ }^{41}$ Cf. V.G. FELLER, "A Igreja que queremos para o novo milênio", in REB, 59 / n 234 (1999) 263-264. Ver a classificação de J. Comblin em : J. COMBLIN, Op. cit., pp. 148"151 e de L. Boff, em "O futuro do cristianismo no Brasil: fonte ou espelho?", in L. BOFF, Ética da vida, Brasília, 1999, p. 159-171.
} 
al; f) Marginalização religiosa: o mundo do crime, da prostituição, das drogas, dos menores abandonados, dos sofredores de rua etc.

Na opinião pública brasileira, a Renovação Carismática Católica ${ }^{42}$ foi, a princípio, identificada com os movimentos neopentecostais evangélicos ${ }^{43}$, o que obrigou o movimento a efetuar algumas mudanças ${ }^{44}$ no sentido de assegurar sua identidade católica: a) em primeiro lugar, deixou de se chamar pentecostalismo católico, como era o caso nos USA, de onde veio para o Brasil. Aqui acentuou certos traços do catolicismo: devoção a Nossa Senhora, sacramentos, devoção ao papa e o caráter apologético de seu discurso; apresentou a igreja católica como a única e verdadeira religião frente às religiões mediúnicas, aos pentecostais e aos esotéricos, o que facilitou a atração de católicos não praticantes e sua influência cada vez maior em todo o conjunto da pastoral da igreja católica; b) a ampliação do público na direção das classes populares, entrando em profunda sintonia com o mundo simbólico mítico e miraculoso, inclusive o imaginário demoníaco, presente na religiosidade popular tradicional. "Utilizando-se de recursos religiosos (exorcismo, libertação, milagre, cura) e incorporando habilmente elementos subjetivos (emoção, sentimento, conforto, tranqüilidade), os carismáticos conseguem amortecer a aflição sofrida pelos fiéis diante de realidades sociais caóticas, nas quais as agências seculares (estado, escola, direito, saúde...) estão cada vez mais ausentes" ${ }^{45}$. De forma semelhante ao neopentecostalismo, na renovação carismática católica o demônio se transforma em elemento explicativo da realidade e se consegue, a partir do temor do demônio, rearticular o mundo vivido dos fiéis através de explicações plausíveis para os conflitos pessoais e coletivos. Oferece, assim, a estas pessoas, fragilizadas em sua identidade, comunidades emocionais com experiências de cura física, êxtase religioso, orações de louvor, manifestações festivas da fé, as concentrações de massa, milagres e glossolalia. A religião se torna o lugar do "reconhecimento pessoal, de acolhida, de autovalorização, de alívio, de expressão de suas vivências" ${ }^{46}$; c) Sua forma de participação política ${ }^{47}$ : trata-se de ocupar cargos públicos com a intenção

\footnotetext{
42 Cf. P. A. ORO, Avanço pentecostal e reação católica, Petrópolis, 1996. R. PRANDI, Um sopro do Espírito: a renovação conservadora do catolicismo carismático, São Paulo, 1997.

${ }^{43} \mathrm{Ou}$ apresentada na mídia como resposta católica ao pentecostalismo evangélico, ou mesmo como o movimento de massas católico alternativo às CEBs, enfim como a forma da igreja romano-católica adequada à modernidade. Cf. J. A. S. IULIANELLI, Op. cit., p.77.

${ }^{44}$ Cf. B. CARRANZA, Renovação carismática católica: origens, mudanças e tendências, in: M.F. DOS ANJOS (org.), Sob o Fogo..., Op. cit., pp. 49ss.

${ }^{45}$ Cf. B. CARRANZA, Op. cit., pp. 50-51.

${ }^{46}$ Cf. J.B. LIBANIO, Fascínio ..., Op. cit., p.6.

${ }^{47}$ Cf. J. MIRANDA, Carisma, sociedade e política. Novas linguagens do Religioso e do Político, Rio de Janeiro, 1999.
} 
clara de legislar em nome do movimento, da igreja e de Deus na perspectiva de uma ética individualista em que a conversão individual é condição para a atuação no social e é, portanto, decorrência de uma renovação interior. A política é considerada uma luta direta e unicamente moral, sem que se faça a menor idéia dos elementos sistêmicos que marcam as relações das pessoas na sociedade e sem que os partidos políticos tenham alguma significação uma vez que o que importa é a adesão à igreja ou ao movimento religioso ${ }^{48}$. O objetivo concretamente proposto ${ }^{49}$ é, sobretudo, o de contrapor-se aos projetos considerados inaceitáveis pela igreja como a união entre homossexuais, o aborto, a eutanásia, etc.; d) O grande salto qualitativo, com profundas conseqüências para o movimento, foi o uso dos meios de comunicação social com a produção de bens religiosos eletrônicos, o que tornou possível uma enorme penetração no seio das massas. $\mathrm{O}$ discurso tradicional da igreja católica chega à opinião pública através de meios ultramodernos, fazendo da televisão uma extensão das paróquias e dos grupos de oração. Foi a partir daqui que se destacaram os padres cantores, atraindo milhares de pessoas em busca da comunhão com Deus e da libertação de seus males nas missas. O fato novo importante neste contexto é que os meios eletrônicos alteraram a renovação carismática "que enquanto fenômeno popular manteve-se perto de trinta anos fora do olhar da mídia (de seu surgimento em 1967 até 1994)" 50 . A grande criatividade que marcava o movimento desapareceu cedendo lugar às determinações universais que a mídia produz.

O catolicismo carismático repõe um problema que tem acompanhado toda a história da igreja e que, no Brasil, em virtude de seu dualismo básico, é um problema particularmente grave, ou seja, o da relação entre o catolicismo erudito e o catolicismo popular, agora em questão, sobretudo no discurso sobre o demônio, que é elemento fundamental no simbolismo tradicional. Hoje, a psicologia e a parapsicologia nos permitem interpretar a possessão demoníaca como um fenômeno decorrente de processos inconscientes ${ }^{51}$, movidos por perturbações psíquicas nas quais pode influenciar a figura do demônio através da fantasia e da

\footnotetext{
${ }^{48}$ Cf. J.A.S. IULIANELLI, “'Pega ele Jesus': RCC e CEBS no Brasil, Política e Modernidade", REB, 59 / $\mathrm{n}^{\circ} 233$ (1999) 76.

${ }^{49}$ J.A.S. Iulianelli acha importante considerar também as expectativas do sistema vigente em relação a estes movimentos religiosos. Cf. J.A.S. IULIANELLI, Op. cit., p. 77: “...a política de ajuste neoliberal necessita de um povo que aceite os pressupostos básicos do concorrencialismo desmesurado e sacrificial que estamos vivendo: a docilidade e o aprofundamento da anomia generalizada"...

${ }^{50}$ Cf. F. A. JÚNIOR, Experiência e Elaboração da teologia: ver como somos vistos, in M.F. dos ANJOS, Sob o Fogo..., Op. cit., p. 185.

${ }^{51}$ Cf. J. SOMETTI, O Maravilhoso: Pastoral e Teologia, São Paulo, 1991, pp. 132ss.
} 
imaginação, uma vez que as imagens exercem enorme poder sobre nós, podendo desencadear inúmeras reações. Com a perda da consciência, a pessoa fica com sua mente ofuscada e pode manifestar o que está em seu inconsciente; na medida em que volta ao estado consciente, crêem que se trata de expulsão do demônio. Ocorre que setores da renovação carismática rejeitam a psicologia e, sobretudo, a parapsicologia, retomando assim o conflito moderno entre ciência e religião.

O cristianismo, em contato com a filosofia grega, empreendeu um esforço secular de articulação racional de seu conteúdo. Nos movimentos carismáticos, recuperam-se a emoção, o sentimento, a subjetividade, os gestos corporais e a dança nas expressões de culto, descarregando tensões e destruindo bloqueios em nome de um Deus bondoso e misericordioso, sem, contudo, através disto, mudar as concepções tradicionais sobre a corporeidade e a sexualidade. Tudo isto está criando uma nova forma de manifestação do catolicismo, embora o conteúdo tradicional permaneça o mesmo, às vezes, até mais exacerbado, como é o caso da moral sexual. Há muito mais liberdade nas formas de oração, e a espontaneidade tem primazia sobre o instituído, o que tem ajudado a muitos a reencontrar o valor da oração espontânea e de louvor. Insiste-se em que a oração é, acima de tudo, encontro com Deus, o que valoriza as emoç̃̃es humanas como ajuda na aceitação de si mesmo na medida em que se descobre a profundidade do amor misericordioso do Deus, que habita em cada um. Aqui a cura é um elemento essencial de resposta às aflições que o povo pobre experimenta em seu cotidiano. De qualquer forma, o movimento carismático se entende a si mesmo como um movimento de renovação interior, que interpela os cristãos a terem uma experiência vivida da ação de Deus, que deve desembocar numa opção fundamental de vida, através de sua entrega a Deus ${ }^{52}$. Um elemento novo é a insistência de que a ação do Espírito se manifesta sensivelmente através das orações em línguas, profecias, interpretações, cura, etc.

\section{C) Possibilidades de interpretação}

Toda experiência religiosa, apesar de possuir um espaço próprio e irredutível, ocorre sempre dentro de um contexto humano específico; consequentemente tem condicionamentos psicológicos, sociológicos ou

\footnotetext{
${ }^{52}$ Chega-se a falar de um "novo pentecostes". Cf. J. SOMETTI, Op. cit., p.127: " 'Sob a ação do Espírito Santo' as pessoas experimentam a libertação interior de sentimentos de culpa, de complexos de inferioridade, de angústia, de ódios, criando no lugar segurança, alegria, amor ao próximo, discernimento da vontade de Deus e fidelidade aos próprios compromissos".
} 
culturais $^{53}$. Por esta razão é sempre acompanhada de certa ambigüidade que abre espaço a diferentes interpretações. No que diz respeito aos novos movimentos religiosos, apresentam-se pelo menos três possíveis leituras:

1) A religião reduzida a uma simples busca de realização do ser humano. Esta perspectiva nos é apresentada de forma mais clara por G. Minois ${ }^{54}$. Sua análise parte de uma leitura do clima espiritual deste fim de século: num contexto de ceticismo generalizado, tanto a fé como o ateísmo perdem sua razão de ser e têm muita dificuldade em definir-se. A referência a um conteúdo determinado de fé tende a desaparecer e a religiosidade que subsiste é uma religiosidade sem credo $^{55}$, capaz das mais diferentes interpretações. Isto quer dizer que a religião não desapareceu propriamente do contexto societário das sociedades pós-modernas, mas seu conteúdo foi profundamente transformado na medida em que foi radicalmente secularizado. Fala-se assim de Deus, mas ele está cada vez mais ausente, uma vez que o que se busca, acima de tudo, é a realização do ser humano, o equilíbrio interior, a serenidade e a satisfação de todas as necessidades vitais, ou, nas correntes que têm consciência maior política, a justiça, a solidariedade e a paz, mas num plano estritamente horizontal. O que caracteriza a religiosidade de nossa época, segundo G. Minois, é que, na prática, ela é uma religiosidade sem Deus, em que a linguagem sobre o sagrado, até mesmo sobre o divino, permanece no nível da pura imanência. Neste sentido, a denominação "novos movimentos religiosos" é ambígua, a não ser que se amplie o significado de religião. $\mathrm{O}$ que na realidade existe hoje, para o autor, é uma decomposição do religioso no mágico, ou, então, numa espécie de novo humanismo. $\mathrm{O}$ centro deste novo humanismo é a transformação do próprio eu pela mediação de técnicas psicocorporais, que buscam a realização da felicidade na terra ${ }^{56}$.

2) A religião enquanto terapia diante de um processo histórico portador de tantas violências. Nesta perspectiva, segundo J.B. Libanio ${ }^{57}$, a religião pode transformar-se numa "ilha de fantasia", pois as pessoas podem encontrar aqui na participação, durante longas horas, nas orações coletivas em busca de terapia e cura corporal espiritual, o que

${ }_{53}$ Cf. J. SUDBRACK, Wege zur Gottesmystik, Einsiedeln, 1980, pp. 9-49.

${ }^{54}$ Cf. G. MINOIS, Histoire de l'athéisme. Les incroyants dans le monde des origine à nos jours, Paris, 1998.

${ }^{55}$ Uma religião não metafísica na expressão de G. VATTIMO. Cf. G. VATTIMO, “O rasto do rasto", in J. DERRIDA / G. VATTIMO et alii, Op. cit., pp. 95-113.

${ }^{56}$ Cf. J.B. LIBANIO, Cenários da Igreja, São Paulo, 1999, p. 50: “A religião torna-se mais solução de problemas que uma relação de culto, adoração do ser humano a Deus".

${ }^{57}$ Cf. J.B. LIBANIO, "O Sagrado na Pós-Modernidade", in Cl. CALIMAN (org.), Op. cit., pp. 67-68. Cf. J. SOMETTI, Op. cit., pp 148-149. 
o sistema não oferece, sem precisar combatê-lo ou transformá-lo. Sobretudo, a religião oferece aquilo que falta numa sociedade marcada por tantas angústias: paz e segurança.

3) Chance de recuperação do caráter iniciático e mistagógico do cristianismo. Em primeiro lugar, a religião emerge como crítica à modernidade, na medida em que abre um espaço de consideração da realidade para além dos limites da razão técnico-científica: lê a realidade a partir do Absoluto; com isto mostra o lado do mistério da realidade e aponta para a presença de Deus em tudo ${ }^{58}$, pois se torna mais claro que, quando se fala de Deus, fala-se do fundamento e do sentido absolutos que sustentam toda a realidade. Sendo assim, cada realidade se revela como forma específica de manifestação do Absoluto: o radicalmente Transcendente, em virtude mesmo de sua transcendência radical, está presente em tudo, perpassa tudo e é radicalmente imanente a tudo.

A grande chance aqui é não só compreender a religião como conhecimento do Absoluto, e de tudo à luz do Absoluto, mas como "fruição do Absoluto" 59 , como impulso de aproximação, de comunhão com o Absoluto como Mistério último que envolve a vida humana ${ }^{60}$. Aqui há uma antropologia pressuposta: o ser humano é, em última instância, enquanto ser espiritual, presença do Absoluto. No mais íntimo do espírito, o Absoluto está presente na sua radical transcendência e na sua radical imanência. Daí a sedução do mistério: "O princípio de toda experiência religiosa encontra um denominador comum no desejo seduzido, a inclinação fascinada e irresistivelmente atraída pelo mistério do Outro que envolve, seduz e apaixona com sua beleza e sua diferença, que provoca o impulso incontrolável, de aproximação, abraço e união" ${ }^{\prime \prime 1}$. Também hoje os seres humanos continuam a se experimentar como seres frágeis e limitados, mas chamados a entrar em comunhão com o Mistério ilimitado e, portanto, "... se percebem habitados pelo desejo ardente e incontrolável de entrar em comunhão com esta incompreensível realidade que se chama sagrado" ${ }^{62}$.

\footnotetext{
${ }^{58}$ Cf. L. BOFF, Op. cit., p. 170: “...os brasileiros nos fizemos um povo místico, capaz de ver a realidade transfigurada e impregnada por Deus e por seus santos .... . Talvez esta visão mística do mundo constitua uma das maiores contribuições que a cultura brasileira possa dar à cultura mundial emergente, tão pouco espiritual e tão raramente sensível à leveza, ao humor e à harmonia dos contrários".

${ }^{59}$ Cf. J.B. LIBANIO, Cenários ..., Op. cit., p. 53: “ 'Experiência' será a palavra mágica. O sagrado impor-se-á por sua força de sedução".

${ }^{60}$ Cf. C. H. de L. VAZ, "Mística e Política: a experiência mística na tradição ocidental", in Sintese Nova Fase, vol. 19 / n 59 (1992) 496.

${ }^{61}$ Cf. M.C.L. BINGEMER, A Sedução do Sagrado, in C. CALIMAN (org.), Op. cit., p. 80 .

${ }^{62}$ Idem, Op. cit., p. 83.
} 
Apesar da ambigüidade dos movimentos religiosos de hoje no interior das igrejas cristãs, certamente estes constituem um grande desafio: "... o cristianismo necessita de homens e mulheres que cultivem uma loucura, uma 'paixão por Deus' "63. Só assim poderá responder aos questionamentos que vêm da religiosidade que marca nossa épo$\mathrm{ca}^{64}$.

Manfredo Araújo de Oliveira, obteve o grau de Mestre em Teologia na Pontifícia Universidade Gregoriana de Roma (1966); Doutorado em Filosofia pela Universidade Ludwig Maximilian de Munique, Alemanha. Entre suas obras contam: Subjektivität und Vermittlung, München: Fink, 1973. Ética e Sociabilidade, São Paulo: Loyola, 1993; Ética e Racionalidade Moderna, São Paulo: Loyola, 1993. Sobre a Fundamentação, Porto Alegre: Edipucrs, 1993. Ética e Práxis histórica, São Paulo: Ática, 1995. Economia e Ética, São Paulo: Ática, 1995. Tópicos sobre Dialética, Porto Alegre: Edipucrs, 1996. Reviravolta lingüístico-pragmática na filosofia contemporânea, São Paulo: Loyola, 1996.

Endereço: Rua Catão Mamed, 218, Apto. 603

60140-110 Fortaleza - CE

e-mail: oliveira@centernet.psi.br

\footnotetext{
${ }^{63}$ Cf. J.B. LIBANIO, Op. cit., p. 75. L. BOFF, Op. cit., p. 188: Os milhões de carismáticos mostram a possibilidade de realizar a igreja num outro modelo, sem trair os valores da grande tradição".

${ }_{64}$ Para alguns autores, isto significa, para as igrejas do Ocidente, de certo modo, um retorno ao Oriente. Cf. C. CAMPBELL, "A orientalização do Ocidente: Reflexões sobre uma nova teodicéia para um novo milênio", in Religião e Sociedade, 18 / n 1 (1997) 5-29. J.B. LIBANIO, Cenários ... , Op. cit., p. 57: “Com o cisma do Oriente no século XI, a igreja do Ocidente acentuou ainda mais sua perspectiva jurídica, objetiva, pragmática e intelectual. A dimensão simbólica, icônica, espiritual, festiva é mais bem conservada no Oriente".
} 